\title{
STUDIES OF NIACIN REQUIREMENT IN MAN. I. EXPERI- MENTAL PELLAGRA IN SUBJECTS ON CORN DIETS LOW IN NIACIN AND TRYPTOPHAN ${ }^{1}$
}

\author{
By GRACE A. GOLDSMITH, HERBERT P. SARETT, U. D. REGISTER, AND \\ JANIS GIBBENS \\ (From the Nutrition Research Laboratory, Departments of Medicine and Biochemistry, Tulane
University School of Medicine, and the Charity Hospital of Louisiana at New Orleans, La.)
}

(Submitted for publication January 11, 1952; accepted March 24, 1952)

Early attempts to estimate human niacin requirement were based on calculations of the niacin content of pellagragenic and nonpellagragenic diets $(1,2)$. It was appreciated that the protein content of the diet was in some way related to niacin requirement. Recent studies showing that the amino acid tryptophan is converted in part to niacin compounds in man (3-5) may explain the above relationship, and also the pellagra preventive effect of foods which are low in niacin but rich in "good" protein.

The present experiments were designed to study niacin requirement in man with diets of known tryptophan content. Estimation of minimum tryptophan requirement for nitrogen balance (6) permits formulation of diets containing little excess tryptophan which may be converted to niacin. The discovery of the major metabolites of niacin, namely $\mathrm{N}^{1}$-methylnicotinamide $\left(\mathrm{N}^{1}-\mathrm{Me}\right)$ and the 6-pyridone of $\mathrm{N}^{1}$-methylnicotinamide (pyridone), and the development of methods for the measurement of these compounds in urine, now permit more complete studies of niacin metabolism (7-11).

Seven subjects were maintained on diets low in niacin and tryptophan for from 40 to 135 days and the urinary excretion of niacin metabolites was determined. Clinical signs of pellagra developed in the three subjects who remained on one of these diets for more than 50 days.

\section{METHODS}

The seven subjects were white females, 25 to 54 years of age, who were found to be essentially free of organic

\footnotetext{
1 , This work was supported by grants from the Nutrition Foundation, Inc., The Roche Anniversary Foundation, the Williams-Waterman Fund of the Research Corporation, and the Division of Research Grants and Fellowships of the National Institutes of Health, United States Public Health Service.
}

disease and who had some type of psychoneurosis. They were maintained in a metabolism ward and were ambulatory throughout the experimental period. Frequent clinical examinations were carried out for any signs which might suggest nutritional deficiency. Basal diets were carefully weighed and administered under strict supervision.

The diet for two complete days was analyzed at intervals for niacin, tryptophan and total nitrogen. The diet for each meal was blended with water in a Waring blendor to give a total volume of 1,000 to $1,500 \mathrm{ml}$. Aliquots of this material were autoclaved in $1 \mathrm{~N}$ sulfuric acid solution for $\mathbf{4 5}$ minutes, neutralized and analyzed for niacin microbiologically, using L. arabinosus (12). This organism was also employed for tryptophan analysis using aliquots of the homogenate which had been autoclaved in $5 \mathrm{~N}$ sodium hydroxide in the presence of cysteine (13). For these analyses $15 \mathrm{ml}$. portions of $8 \mathrm{~N}$ sodium hydroxide solution were placed in $125 \mathrm{ml}$. Erlenmeyer flasks and $400 \mathrm{mg}$. of cysteine and $10 \mathrm{ml}$. of the blended diet were rapidly added. These were covered at once with beakers and autoclaved for six hours at $121^{\circ} \mathrm{C}$. After neutralization with hydrochloric acid, the solutions were diluted to $100 \mathrm{ml}$., filtered and analyzed. Under these conditions it is assumed that all tryptophan. liberated from the proteins was racemized and was present as D,L-tryptophan. Although it is possible that some tryptophan in the proteins may have been destroyed by this procedure, L- or D,L-tryptophan added to the samples was not destroyed and treatment of $\mathrm{L}$ - or D,L-tryptophan alone with these reagents resulted in 90 to $100 \%$ recovery. Analyses of the diets and of individual foods gave reproducible results. Nitrogen was determined by the macro-Kjeldahl method.

All urine was collected for 24 hour periods in dark bottles containing $5 \mathrm{ml}$. of glacial acetic acid and kept in the refrigerator until pooled for analysis. In long term experiments, it was found desirable to pool the urine in four day periods. A portion of each pooled urine was neutralized to $\mathrm{pH} 6.9$, and stored in the frozen state in several $16 \times 150 \mathrm{~mm}$. screw cap tubes until analyzed. Microbiological methods were used for determination of niacin (12), quinolinic acid (14) and tryptophan (5). Fluorometric methods for determination of $\mathrm{N}^{1}$-methylnicotinamide ( $\mathrm{N}^{1-\mathrm{Me}}$ ) (10) and the 6-pyridone of $\mathrm{N}^{1}-\mathrm{Me}$ (pyridone) (11) were modified for use in this laboratory. The procedure for measurement of $\mathrm{N}^{1-M e}$ is 
TABLE I

Corn diet low in niacin and tryptophan*

$\quad$ Breakfast
Orange or grapefruit
juice
Corn grits (dry weight)
White bread
Oleomargarine
Sugar

gm.

200

50

30

20

Dinner

Mor beef

Rice (dry weight)

Beets or carrots $\dagger$

Corn bread

Oleomargarine

Fruit cocktail or apple sauce

Apple juice

* The unenriched white flour (Gold Medal) was generously furnished by General Mills, Inc., through the courtesy of Dr. H.S. Faulkner. The unenriched corn meal and grits were generously provided by the Quaker Oats Company, through the courtesy of Dr. F. N. Peters. Mor Beef was kindly supplied by Wilson and Company, Inc., through the courtesy of Dr. E. J. Czarnetzky.

$\dagger$ Canned, drained weight, given alternately.

White flour and corn products were unenriched.

Analysis of diet: nitrogen $7.0 \mathrm{gm}$., niacin $4.7 \mathrm{mg}$., tryptophan $190 \mathrm{mg}$.

Energy value: approximately 2,000 calories.

sufficiently sensitive to detect excretion as low as $0.5 \mathrm{mg}$. daily and at this level, values are reproducible to within $20 \%$. The method for estimation of the pyridone is much less sensitive and may fail to detect excretion below $1 \mathrm{mg}$. daily. Reproducibility of values below $2 \mathrm{mg}$. per day is poor and the findings may vary as much as $50 \%$. The 24-hour excretion of $\mathrm{N}^{1}-\mathrm{Me}$ and of pyridone following an oral test dose of $50 \mathrm{mg}$. of niacinamide was measured in some of the subjects at the beginning and end of the period of dietary restriction in order to evaluate changes in body stores of niacin.

All urines were analyzed for total nitrogen using the Kjeldahl procedure. Creatinine analyses using alkaline picrate reagent were performed to check completeness of urine collection. Stools were collected for five day periods on several occasions during the course of some of the experiments and fecal nitrogen was determined on aliquots of the homogenates.

Other laboratory tests which were carried out at intervals include the following: gastric analysis, complete blood count, concentration of urea nitrogen in blood and of proteins in serum, glucose tolerance test, basal metabolic rate and liver function tests. ${ }^{2}$

Two experimental diets were formulated to provide niacin in an amount comparable to that reported in some

2 Liver function tests included thymol, zinc and lipid turbidity, cephalin and thymol flocculation, level of serum bilirubin, and bromsulphalein excretion. These tests were performed through the courtesy of Drs. Roy $\mathrm{H}$. Turner, J. Robert Snavely, and William H. Goldwater of the Department of Medicine. pellagragenic diets $(1,2)$ and tryptophan in a quantity sufficient to fulfill the minimal requirement for maintenance of nitrogen equilibrium (6). One diet which contained $89 \mathrm{gm}$. of unenriched corn products was designated the "corn" diet (Table I). The other which contained unenriched wheat flour and farina in place of the corn products was designated the "wheat" diet. The energy value of the basal diets was adjusted to individual need by modifying the sugar and oleomargarine content and varied from 1,700 to 2,000 calories.

In general, each of the subjects consumed all of the food presented each day, except subject 4 who developed anorexia when signs of pellagra appeared. The analysis of the "corn" diet on three separate occasions gave values of 4.7, 4.7, and $4.3 \mathrm{mg}$. of niacin, 187, 194 and 178 $\mathrm{mg}$. of tryptophan, and 7.0, 7.1 and $6.9 \mathrm{gm}$. of nitrogen. The "wheat" diet was found to contain $5.7 \mathrm{mg}$. of niacin, $230 \mathrm{mg}$. of tryptophan and $7.0 \mathrm{gm}$. of nitrogen. The content of other nutrients in these diets was calculated to be as follows: vitamin A 11,000 I.U., thiamine $0.5 \mathrm{mg}$., riboflavin $0.5 \mathrm{mg}$., ascorbic acid $120 \mathrm{mg}$., calcium $0.2 \mathrm{gm}$. and iron $7 \mathrm{mg}$. The following vitamins ${ }^{3}$ were added to the diet of each subject to avoid complicating deficiencies : thiamine $1 \mathrm{mg}$., riboflavin $1.5 \mathrm{mg}$., pantothenic acid $5 \mathrm{mg}$. and pyridoxine $5 \mathrm{mg}$. Half of the supplement was given with breakfast and half with the noon meal. Two subjects (Nos. 6 and 7) received, in addition, folic acid $2.5 \mathrm{mg}$., and vitamin $\mathrm{B}_{12} 5 \mu \mathrm{g}$., daily. Subject 7 received a supplement of $2 \mathrm{mg}$. of niacinamide daily, $0.7 \mathrm{mg}$. with each meal.

The three subjects (Nos. 4, 5 and 6) who developed signs of pellagra were treated with either niacinamide or tryptophan, ${ }^{3}$ and rehabilitation was followed.

\section{RESULTS}

In a preliminary experiment, subjects 1 and 2 were maintained on the "corn" diet for 40 and 42

TABLE II

Urinary excretion of $N^{1}-M e$ after various lengths of time on the "corn" or "wheat" diet

\begin{tabular}{c|c|c|c|c|c|c}
\hline \multirow{3}{*}{ Subject } & \multirow{3}{*}{ Diet } & \multicolumn{5}{|c}{ N1-Me excretion, mg. per day } \\
\cline { 3 - 7 } & & \multicolumn{5}{|c}{ Days } \\
\cline { 3 - 7 } & & $2-13$ & $14-25$ & $26-41$ & $42-61$ & $62-95$ \\
\hline $1^{*}$ & Corn & 1.8 & 1.6 & 0.9 & - & - \\
$2 \dagger$ & Corn & 2.1 & 1.4 & 1.2 & - & - \\
$3 \ddagger$ & Wheat & 1.9 & 1.5 & 1.4 & 1.3 & 1.1 \\
\hline
\end{tabular}

* Subject 1 (V. S.) female, age 43 , weight $66 \mathrm{Kg}$.

† Subject 2 (L. M.) female, age 49 , weight $65 \mathrm{Kg}$.

‡ Subject 3 (R. L.) female, age 25 , weight $39.5 \mathrm{Kg}$.

3 The vitamin and tryptophan supplements used in this study were generously furnished by Winthrop-Stearns Chemical Company, Inc., through the courtesy of $\mathrm{Mr}$. Kenneth Smoot. 
TABLE III

Clinical findings in three subjects maintained on the "corn" diet low in niacin and tryptophan

\begin{tabular}{|c|c|c|c|}
\hline $\begin{array}{l}\text { Days* after } \\
\text { institution } \\
\text { of diet }\end{array}$ & $\begin{array}{l}\text { Subject 4-(L. M. }{ }^{\text {M. }} \text { - } \\
\text { Age 49, Wgt. } 65 \mathrm{Kg} .\end{array}$ & $\begin{array}{l}\text { Subject 5-(H. K.) } \\
\text { Age 31, Wgt. } 54.5 \text { Kg. }\end{array}$ & $\begin{array}{l}\text { Subject 6-(R. C. } \\
\text { Age 54, Wgt. } 44.5 \text { Kg. }\end{array}$ \\
\hline $50-59$ & $\begin{array}{l}\text { Heartburn, weakness. } \\
\text { Atrophy tongue papillae. }\end{array}$ & $\begin{array}{l}\text { Cheilosis (transient). } \\
\text { Menstruation absent. }\end{array}$ & Dermatitis (perirectal). \\
\hline $60-69$ & $\begin{array}{l}\text { Decreased activity, apathy. } \\
\text { White patch under tongue. } \\
\text { Dermatitis (vulval, perirectal). }\end{array}$ & $\begin{array}{l}\text { Atrophy tongue papillae. } \\
\text { Elbows rough. }\end{array}$ & $\begin{array}{l}\text { Red tongue papillae. } \\
\text { Heartburn. } \\
\text { Diarrhea (one day). }\end{array}$ \\
\hline $70-79$ & $\begin{array}{l}\text { Weakness, confined to bed. } \\
\text { Mouth sore, unable to use false } \\
\text { teeth, anorexia, indigestion. } \\
\text { Cheilosis, angular stomatitis. }\end{array}$ & $\begin{array}{l}\text { Palpitation. } \\
\text { Fissures of tongue. }\end{array}$ & Numerous vague complaints. \\
\hline $80-89$ & $\begin{array}{l}\text { Depression, dysphagia. } \\
\text { "Raw" sensation mouth to rectum. } \\
\text { Severe glossitis. Ery thema, } \\
\text { swelling of oral, vaginal, rectal } \\
\text { mucosa. } \\
\text { Diarrhea, small ulcers vulva. } \\
\text { Bleeding (nose, intestine). } \\
\text { Niacin R 82nd day. }\end{array}$ & $\begin{array}{l}\text { Cheilosis (transient). } \\
\text { Red tongue papillae. }\end{array}$ & Atrophy tongue papillae at margin. \\
\hline 90-99 & & $\begin{array}{l}\text { Tongue painful. Skin dry. } \\
\text { Angles mouth scaling. } \\
\text { Herpes of lip. }\end{array}$ & $\begin{array}{l}\text { Diarrhea (one day). } \\
\text { Small ulcer of tongue. }\end{array}$ \\
\hline 100-109 & & Depression, hot flushes. & $\begin{array}{l}\text { Diarrhea (intermittent). } \\
\text { Mouth sore, erythema under } \\
\text { tongue. }\end{array}$ \\
\hline $110-119$ & . & $\begin{array}{l}\text { Tongue papillae swollen. } \\
\text { Lesion left angle mouth. } \\
\text { Skin thick and pigmented over } \\
\text { finger joints. Skin of elbows } \\
\text { thick, dry scaling. }\end{array}$ & $\begin{array}{l}\text { Anorexia, heartburn, cramping } \\
\text { abdominal pain, nausea. } \\
\text { Erythema oral mucosa, white } \\
\text { patches under tongue, glossitis. } \\
\text { Diarrhea. Skin thick, pigmented, } \\
\text { scaling over terminal phalanges } \\
\text { fingers, between thumb and 1st } \\
\text { finger. } \\
\text { Redness paronychial skin. } \\
\text { Niacin } \mathbf{R} 118 \text { th day. }\end{array}$ \\
\hline $120-129$ & . & $\begin{array}{l}\text { Skin red, pigmented between } \\
\text { thumb and 1st finger (typical } \\
\text { pellagrous lesion). Palms and } \\
\text { soles dry, scaling. } \\
\text { Angular stomatitis. }\end{array}$ & $\because$ \\
\hline $130-139$ & & $\begin{array}{l}\text { Dermatitis nose, chin, nasolabial } \\
\text { folds, perineum. } \\
\text { Herpes, cheilosis. } \\
\text { Niacin } \mathbf{R} 135 \text { th day. }\end{array}$ & \\
\hline
\end{tabular}

* The corn diet was begun on September 10, 1950 in subject 4, on September 12, 1950 in subject 5 and on January 18,1950 in subject 6 .

days and subject 3 on the "wheat" diet for 95 days. No symptoms or signs of nutritional deficiency developed. Urinary excretion of nitrogen remained constant in each subject, mean values being $6.1,5.8$ and $5.2 \mathrm{gm}$. daily, respectively. In the two subjects who received the "corn" diet, the excretion of $\mathrm{N}^{1}-\mathrm{Me}$ decreased to mean levels of 0.9 and $1.2 \mathrm{mg}$. daily in the last two weeks of the experimental period (Table II). The excretion of pyridone fell to less than $2 \mathrm{mg}$. within the first two weeks of study and after this time no pyridone could be detected. Excretion of tryptophan averaged 5 to $6 \mathrm{mg}$. per day.

In subject 3, who received the "wheat" diet, excretion of $\mathrm{N}^{1}-\mathrm{Me}$ fell more slowly than in the subjects who received the "corn" diet (Table II). 
The decrease in pyridone was approximately the same as that found on the "corn" diet. Mean tryptophan excretion was $11 \mathrm{mg}$. daily throughout the period of study. The "wheat" diet contained approximately $1.0 \mathrm{mg}$. more niacin and $40 \mathrm{mg}$. more tryptophan than the "corn" diet.

Since excretion of niacin metabolites appeared to fall more rapidly on the "corn" than on the "wheat" diet and since no evidence of niacin deficiency was observed after 95 days on the "wheat" diet, long term studies were carried out with the corn regimen. Subjects 4,5 , and 6 were maintained on this diet for 81,135 , and 117 days, respectively, following which niacinamide or tryptophan was administered. Each of the subjects developed signs of niacin deficiency beginning between the 50th and 60th days. Findings included most of the lesions which have been encountered in endemic pellagra (Table III). Anorexia, indigestion and diarrhea occurred in subjects 4 and 6. In subject 4, diarrhea was associated with gross bleeding from the intestinal tract; the mucous membranes became fiery red and swollen and she complained that she felt "raw" from her mouth to her rectum. Atrophy of the tongue papillae occurred in each subject, while in two, glossitis became severe. In one of these, the tongue was bright red and swollen, in the other, moderately red with a clearly delineated area of papillary atrophy on the dorsum. Interesting lesions which occurred in these two subjects were white elevated patches, surrounded by erythema, in the mucous membrane under the tongue and between the gums and cheeks. These lesions could not be scraped off, did not ulcerate and gradually increased in size until treatment was instituted.

Dermatitis of the vulva, perineum or peri-anal region developed in each subject and dermatitis of the elbows in subjects 4 and 5. Typical pellagrous dermatitis of the hands was observed in subjects 5 and 6 , in whom niacin deficiency developed relatively slowly. In subject 5 , who was maintained on the diet for 135 days, lesions on the hands became red, pigmented, clearly demarcated from normal skin and were symmetrical. This subject also showed dry, thick, slightly pigmented skin over the bridge of the nose and on the chin.

Subjects 4 and 5 developed cheilosis and angular stomatitis and subject 5 , dermatitis in the nasolabial folds, lesions previously observed in experimentally induced riboflavin deficiency. All of the subjects were receiving approximately 2.0 mg. of riboflavin daily. An interesting finding in subject 5 was amenorrhea which persisted from the second month on the basal diet until therapy was instituted. Amenorrhea and other disturbances of the menstrual cycle have been noted frequently in endemic pellagra $(15,16)$.

Depression and apathy were the only mental changes noted. All subjects complained of aching legs and muscle soreness, but these findings could not be considered evidence of nutritional deficiency due to numerous pains which existed prior to initiation of the study. Subject 4 became so weak that she remained in bed during the last few days on the basal diet. No neurological changes were demonstrable in any subject.

Each of the subjects improved rapidly following the addition of niacinamide or tryptophan to the basal diet. Subjects 4 and 5 received niacinamide for 50 and 26 days, respectively, and subject 6 received niacinamide one day ( $50 \mathrm{mg}$.) and, after an interval of six days, was given D,L-tryptophan for 26 days. In subjects 4 and 5, who received therapy with niacinamide, subjective improvement was noted within 24 to 48 hours and diarrhea ceased after the first day. Lesions of the lips and oral mucous membrane healed within one week, except for atrophic tongue papillae which required about a month to return to normal. The pellagrous dermatitis showed improvement beginning on the second day, and the skin of the face and hands was practically normal by the 21 st day. Approximately one month was required for complete healing of the dermatitis of the elbows. In subject 5 , in whom amenorrhea had developed while on the basal diet, menstruation occurred 23 days after niacinamide therapy was instituted. In subject 6 , oral lesions improved following the test dose of $50 \mathrm{mg}$. of niacinamide but did not completely disappear until several days after therapy with tryptophan was instituted. Skin improvement was noted after about two weeks and was essentially complete after the period of tryptophan therapy. At this time regeneration of the lingual papillae was likewise complete.

Urinary excretion of nitrogen and of niacin and tryptophan metabolites was measured in subjects 4,5 , and 6 during the entire course of these 
TABLE IV

Urinary excretion findings in subjects on the "corn" diet and following supplements of niacinamide (NAm) or D,L-tryptophan

\begin{tabular}{|c|c|c|c|c|c|c|c|c|}
\hline Subject & Days & Supplement & Nitrogen & Niacin & $\begin{array}{l}\text { Quino- } \\
\text { linic } \\
\text { acid }\end{array}$ & $\mathrm{N}^{1}-\mathrm{Me}$ & Pyridone & $\begin{array}{c}\text { Trypto- } \\
\text { phan }\end{array}$ \\
\hline $\begin{array}{l}4 \text { (L. M.) } \\
\text { Age } 49 \\
\text { Wgt. } 65 \mathrm{Kg} \text {. }\end{array}$ & \begin{tabular}{|}
$5-21$ \\
$22-41$ \\
$42-61$ \\
$62-81$ \\
$82-85$ \\
$86-93$ \\
$105-109$ \\
$115-126$ \\
128 \\
$129-138+$ \\
$142-1518$ \\
154
\end{tabular} & $\begin{array}{l}\text { None } \\
\text { None } \\
\text { None } \\
\text { None } \\
\text { NAm, } 10 \mathrm{mg} . \text { t.i.d. } \\
\text { NAm, } 10 \mathrm{mg} \text {. t.i.d. } \\
\text { NAm, } 10 \mathrm{mg} \text {. t.i.d. } \\
\text { NAm, } 10 \mathrm{mg} \text {. t.i.d. } \\
\text { NAm, } 50 \mathrm{mg} \text {. test dose } \\
\text { NAm, } 50 \mathrm{mg} \text {. t.i.d. } \\
\text { D,L-tryptophan, } 1 \text { gm. t.i.d. } \\
\text { NAm, } 50 \text { mg. test dose }\end{array}$ & $\begin{array}{l}g m . \\
5.2 \\
5.0 \\
4.9 \\
4.9 \\
4.7 \\
4.4 \\
5.0 \\
4.5 \\
\\
5.1 \\
5.0\end{array}$ & $\begin{array}{l}m g . \\
0.5 \\
0.4 \\
0.3 \\
0.4 \\
0.3 \\
0.3 \\
0.3 \\
0.4 \\
\\
0.8 \\
0.5\end{array}$ & $\begin{array}{l}m g . \\
2.8 \\
2.8 \\
2.5 \\
2.0 \\
2.2 \\
2.1 \\
2.2 \\
2.6 \\
\\
2.0 \\
7.3\end{array}$ & $\begin{array}{r}\text { mg. } \\
1.2 \\
0.8 \\
0.7 \\
0.6 \\
1.2 \\
1.6 \\
2.3 \\
2.9 \\
7.6 \\
19.6 \\
5.9 \\
7.9\end{array}$ & $\begin{array}{c}m g . \\
0-2.5 \\
0^{*} \\
0^{*} \\
0^{*} \\
4.6 \\
7.0 \\
11.8 \\
11.1 \\
21.2 \\
68.5 \\
14.0 \\
17.9\end{array}$ & $\begin{array}{l}m g . \\
5 \\
3 \\
4 \\
4 \\
3 \\
3 \\
4 \\
3 \\
4 \\
40\end{array}$ \\
\hline $\begin{array}{l}5 \text { (H. K.) } \\
\text { Age } 31 \\
\text { Wgt. } 54.5 \mathrm{Kg} .\end{array}$ & \begin{tabular}{|l|}
$4-19$ \\
$20-51$ \\
$52-83$ \\
$84-135$ \\
136 \\
$137-140$ \\
$141-148$ \\
$149-152$ \\
$153-160$ \\
163 \\
$165-1748$ \\
177
\end{tabular} & $\begin{array}{c}\text { None } \\
\text { None } \\
\text { None } \\
\text { None } \\
\text { NAm, } 50 \text { mg. test dose } \\
\text { NAm, 10 mg. t.i.d. } \\
\text { NAm, 10 mg. t.i.d. } \\
\text { NAm, } 25 \text { mg. t.i.d. } \\
\text { NAm, } 25 \text { mg. t.i.d. } \\
\text { NAm, } 50 \text { mg. test dose } \\
\text { D,L-tryptophan, } 1 \text { gm. t.i.d. } \\
\text { NAm, } 50 \text { mg. test dose }\end{array}$ & $\begin{array}{l}4.6 \\
4.7 \\
4.7 \\
4.7 \\
\\
5.2 \\
5.0 \\
5.2 \\
5.2 \\
\\
4.9\end{array}$ & $\begin{array}{l}0.4 \\
0.4 \\
0.3 \\
0.3 \\
\\
0.4 \\
0.5 \\
0.5 \\
0.5 \\
\\
0.5\end{array}$ & $\begin{array}{r}4.3 \\
4.2 \\
4.5 \\
4.3 \\
\\
4.0 \\
3.9 \\
3.9 \\
3.5 \\
\\
17.8\end{array}$ & $\begin{array}{l}0.9 \\
0.7 \\
0.5 \\
0.5 \\
2.4 \\
1.3 \\
2.5 \\
8.0 \\
7.9 \\
7.1 \\
5.6 \\
9.0\end{array}$ & $\begin{array}{c}0.1-1.4 \\
0^{*} \\
0^{*} \\
0^{*} \\
14.3 \\
5.6 \\
9.4 \\
32.0 \\
52.0 \\
22.1 \\
18.0 \\
27.0\end{array}$ & $\begin{array}{l}3 \\
3 \\
3 \\
3 \\
\\
4 \\
3 \\
3 \\
3\end{array}$ \\
\hline $\begin{array}{l}6 \text { (R. C.) } \\
\text { Age } 54 \\
\text { Wgt. } 44.5 \mathrm{Kg} .\end{array}$ & $\begin{array}{c}0 \\
8-15 \\
28-31 \\
44-51 \\
64-71 \\
107-114 \\
118 \\
124-127 \\
128-131 \\
132-143 \\
144-149 \\
152 \\
154-159 \\
160-177\end{array}$ & $\begin{array}{c}\text { NAm, } 50 \text { mg. test dose } \\
\text { None } \\
\text { None } \\
\text { None } \\
\text { None } \\
\text { None } \\
\text { NAm, } 50 \text { mg. test dose } \\
\text { D,L-tryptophan, } 1 \text { gm. t.i.d. } \\
\text { D,L-tryptophan, } 1 \text { gm. t.i.d. } \\
\text { D,L-tryptophan, } 1 \text { gm. t.i.d. } \\
\text { D,L-tryptophan, } 2 \text { gm. t.i.d. } \\
\text { NAm } 50 \text { mg. test dose } \\
\text { NAm } 10 \text { mg. t.i.d. } \\
\text { NAm } 10 \text { mg. t.i.d. }\end{array}$ & $\begin{array}{l}5.6 \\
5.8 \\
5.9 \\
5.6 \\
5.1 \\
\\
5.4 \\
5.6 \\
6.0 \\
5.7 \\
\\
5.8 \\
5.3\end{array}$ & $\begin{array}{l}0.4 \\
0.4 \\
0.3 \\
0.3 \\
0.3 \\
\\
0.3 \\
0.4 \\
0.5 \\
0.5 \\
\\
0.4 \\
0.4\end{array}$ & $\begin{array}{r}2.3 \\
2.7 \\
2.5 \\
2.5 \\
2.3 \\
\\
7.4 \\
8.9 \\
7.3 \\
11.4 \\
\\
2.9 \\
2.8\end{array}$ & $\begin{array}{l}5.0 \\
0.7 \\
0.5 \\
0.5 \\
0.5 \\
0.5 \\
3.8 \\
1.0 \\
2.6 \\
3.9 \\
9.1 \\
9.0 \\
5.4 \\
5.2\end{array}$ & $\begin{array}{c}29.0 \\
0.4-0.7 \\
0^{*} \\
0^{*} \\
0^{*} \\
0^{*} \\
21.3 \\
2.4 \\
11.4 \\
13.5 \\
29.3 \\
30.4 \\
18.1 \\
17.1\end{array}$ & $\begin{array}{r}7 \\
6 \\
6 \\
6 \\
6 \\
\\
40 \\
41 \\
48 \\
85 \\
\\
6 \\
7\end{array}$ \\
\hline $\begin{array}{l}7 \text { (W. H.) } \\
\text { Age } 36 \\
\text { Wgt. } 68 \mathrm{Kg} \text {. }\end{array}$ & $\begin{array}{c}0 \\
2-21 \\
22-61 \\
62-89 \\
90-121 \\
123 \\
125-128 \\
129-136\end{array}$ & $\begin{array}{l}\text { NAm, } 50 \mathrm{mg} . \text { test dose } \\
\text { NAm, } 0.67 \mathrm{mg} . \text { t.i.d. } \\
\text { NAm, } 0.67 \mathrm{mg} \text {. t.i.d. } \\
\text { NAm, } 0.67 \mathrm{mg} \text { t.i.d. } \\
\text { NAm, } 0.67 \mathrm{mg} . \text { t.i.d. } \\
\text { NAm, } 50 \mathrm{mg} \text {. test dose } \\
\text { NAm, } 10 \mathrm{mg} \text {. t.i.d. } \\
\text { NAm, } 10 \mathrm{mg} \text {. t.i.d. }\end{array}$ & $\begin{array}{l}5.7 \\
5.5 \\
5.3 \\
5.0 \\
5.2 \\
5.8\end{array}$ & $\begin{array}{l}0.6 \\
0.5 \\
0.5 \\
0.5 \\
0.5 \\
0.6\end{array}$ & $\begin{array}{l}4.0 \\
3.8 \\
3.5 \\
4.0 \\
3.5 \\
4.5\end{array}$ & $\begin{array}{l}7.8 \\
1.4 \\
1.0 \\
0.9 \\
0.9 \\
3.9 \\
2.0 \\
3.3\end{array}$ & $\begin{array}{c}18.2 \\
0.1-1.2 \\
0^{*} \\
0^{*} \\
0^{*} \\
17.7 \\
9.5 \\
15.2\end{array}$ & $\begin{array}{l}8 \\
6 \\
6 \\
5 \\
5 \\
5\end{array}$ \\
\hline
\end{tabular}

* Non-detectable amounts.

† T.i.d.-administered 3 times daily. with meals.

experiments (Table IV). All subjects remained in nitrogen balance on the basal diet. Fecal nitrogen excretion averaged $1 \mathrm{gm}$. daily in subject 4 and $0.9 \mathrm{gm}$. daily in subject 5 . Total nitrogen excretion per day in stools and urine measured approximately $6 \mathrm{gm}$. in subject $4,5.6 \mathrm{gm}$. in subject 5. Dietary nitrogen was found by analysis to be $7.0 \mathrm{gm}$. Subject 5 gained eight pounds in $\ddagger$ Excretion during last 4 days.

$\$$ Excretion during last 8 days.

weight during an experimental period of 135 days while subject 4 maintained her weight for two months at which time anorexia developed, food intake decreased and she lost three pounds. In subject 6 , fecal nitrogen was not determined, but urinary nitrogen excretion averaged $5.6 \mathrm{gm}$. daily and she gained two pounds in weight.

The excretion of nicotinic acid, tryptophan and 
quinolinic acid (a tryptophan metabolite related to niacin) remained relatively constant on the "corn" diet (Table IV). In each of the three subjects, excretion of $\mathrm{N}^{1}-\mathrm{Me}$ decreased gradually, and after two months remained at 0.5 to $0.6 \mathrm{mg}$. daily. Excretion of pyridone fell rapidly and none could be detected after the first two weeks of the restricted diet.

Following administration of niacinamide to subjects 4 and 5 and of tryptophan to subject 6 , excretion of pyridone increased more rapidly than that of $\mathrm{N}^{1}$-Me. In subject 4 , maximum excretion of $\mathrm{N}^{1}-\mathrm{Me}$ and pyridone, following a daily dose of $30 \mathrm{mg}$. of niacinamide, was not attained until this regimen had been continued for approximately three weeks. In contrast to this, maximum excretion of niacin metabolites was reached in five days in a normal subject who had been receiving a good diet and who was given the same amount of niacinamide. The slow rise in excretion of niacin metabolites following administration of niacinamide in subject 4 suggests that body stores of niacin had been considerably depleted. After niacin stores were replenished by therapy with niacinamide, subjects 4 and 5 received $3 \mathrm{gm}$. of D,L-tryptophan per day, and with this supplement, maximum excretion of niacin metabolites was observed by the third day. In contrast, subject 6 received the same amount of tryptophan after the basal period, and the excretion of $\mathrm{N}^{1}-\mathrm{Me}$ and pyridone continued to increase for more than eight days. Therapy with tryptophan for 26 days appeared to fully replenish the niacin stores of subject 6 , as evidenced by the very rapid rise in excretion of metabolites following subsequent niacinamide administration. The depletion of body niacin stores by the corn regimen is best shown by the test dose studies in subjects 5 and 6 (Table IV). In subject 5 , the excretion of niacin metabolites, following a $50 \mathrm{mg}$. test dose of niacinamide, was $16.7 \mathrm{mg}$. after 135 days on the basal diet as compared to $29.2 \mathrm{mg}$. after therapy with niacinamide (day 163) and $36.0 \mathrm{mg}$. after tryptophan administration (day 177). In subject 6 , excretion of niacin metabolites following the test dose was $34.0 \mathrm{mg}$. before the basal diet was instituted, $25.1 \mathrm{mg}$. after 117 days of the restricted regimen and $39.4 \mathrm{mg}$. after therapy with tryptophan (day 152).
Subject 7 was maintained on the "corn" diet supplemented with $2 \mathrm{mg}$. of niacinamide daily, one-third of this amount with each meal.4 No definite signs of niacin deficiency were observed in a period of 122 days. The patient complained of weakness and dizziness during the last month of study but, in view of the severe psychoneurosis which was present, these symptoms could not be attributed to dietary deficiency. Excretion of $\mathrm{N}^{1}-\mathrm{Me}$ decreased to $0.9 \mathrm{mg}$. per day at the end of two months, and remained at this level during the subsequent period on this diet (Table IV). Only traces of pyridone were detected in the urine after the first two weeks. A comparison of the test dose findings after 122 days on the diet with those obtained before this regimen was started (day 0) suggests a small decrease in body stores of niacin. Following administration of $10 \mathrm{mg}$. of niacinamide three times daily, excretion of $\mathrm{N}^{1}-\mathrm{Me}$ and pyridone increased a little more rapidly than in subjects 4 and 5 who had received the "corn" diet alone for 81 to 135 days.

Creatinine excretion showed a slight downward trend in subjects 5 and 7 during the period of study while no changes were observed in subjects 4 and 6 . Of the other laboratory tests which were conducted in all subjects, no significant change occurred in basal metabolic rate, level of serum proteins or blood urea nitrogen, glucose tolerance or liver function tests. Some impairment of liver function was evident in subject 5 at the beginning of the study but this was not increased during the experimental period. Electrocardiograms were taken at intervals in subjects 6 and 7 and remained normal.

In subject 4 , no free hydrochloric acid was found in the gastric juice after either a test meal or histamine stimulation two months after institution of the "corn" diet. Following therapy with niacinamide, free acid was present in the gastric contents. In subject 5 , a slight reduction in gastric acidity was noted during the corn regimen while no change was observed in subject 6 or 7. Complete hemograms were obtained at weekly intervals in all subjects and changes were observed only in subject 4 . During the period on the "corn" diet mean values decreased as follows:

\footnotetext{
4 The "corn" diet was begun on March 13, 1951.
} 
erythrocyte count from 4.5 to 4.3 million per $\mathrm{cmm}$., hemoglobin from 12.5 to $10.8 \mathrm{gm}$. per 100 ml., hematocrit from 41 to 37 volumes per cent. No improvement followed administration of niacin or tryptophan for 70 days at the end of which time hemoglobin was found to be $10 \mathrm{gm}$. per 100 $\mathrm{ml}$. and the erythrocyte count, 4.1 million per $\mathrm{cmm}$. Improvement followed administration of $5 \mathrm{mg}$. of folic acid three times daily for 12 days and at the end of four weeks the following values were obtained: hemoglobin $11.8 \mathrm{gm}$. per $100 \mathrm{ml}$., hematocrit 40 volumes per cent and erythrocyte count 4.4 million per $\mathrm{cmm}$. Although these changes are small, it seems likely that a mild folic acid deficiency may have been responsible for the anemia encountered in this subject. For this reason the diets of subjects 6 and 7 were supplemented with folic acid.

\section{DISCUSSION}

The "corn" and "wheat" diets used in the present studies of niacin requirement in man were designed to provide low levels of niacin intake and very little tryptophan in excess of that required for maintenance of nitrogen balance. The recent demonstration that some dietary tryptophan is converted to niacin compounds explains some of the difficulties encountered in previous studies of niacin requirement $(1,2)$. It seems pertinent to note that administration of tryptophan leads to an increase in the excretion of niacin metabolites both in normal subjects and in patients with pellagra and brings about healing of the lesions of pellagra (3-5, 17-19).

In three subjects maintained on the "corn" diet containing $4.7 \mathrm{mg}$. niacin and $190 \mathrm{mg}$. tryptophan, supplemented with other B vitamins, clinical evidence of niacin deficiency first appeared in 50 to 60 days. In one subject who received $2 \mathrm{mg}$. of niacinamide daily in addition to the same regimen, no signs of niacin deficiency were observed after 122 days nor were any changes noted in a subject maintained on the "wheat" diet, which contained $5.7 \mathrm{mg}$. niacin and $230 \mathrm{mg}$. tryptophan, for 95 days.

The excretion of $\mathrm{N}^{1}$-Me persisted at a low level, $0.5 \mathrm{mg}$. per day, in the subjects on the "corn" diet during the period in which signs of pellagra were evident. Slightly higher excretion of $\mathrm{N}^{1}-\mathrm{Me}, 0.9$ mg. and $1.1 \mathrm{mg}$. per day, was found after comparable periods of dietary restriction in subjects on the niacinamide supplemented diet and "wheat" diet, respectively. The addition of $2 \mathrm{mg}$. of niacinamide per day to the "corn" diet, or the increase of $1.0 \mathrm{mg}$. in niacin and $40 \mathrm{mg}$. in tryptophan intake which was provided by the "wheat" diet, appeared to prevent the development of niacin deficiency during the period studied. These data suggest that on the "corn" diet, which furnished about $190 \mathrm{mg}$. of tryptophan, the minimal niacin requirement is approximately $7 \mathrm{mg}$. daily. With the "wheat" diet, niacin requirement may be lower because of the larger amount of tryptophan present or because of the difference in the amino acid composition of the protein. The additional $40 \mathrm{mg}$. of tryptophan in the "wheat" diet, as compared with the "corn" diet, may provide about $1 \mathrm{mg}$. of niacin compounds (20). The question of whether corn contains a substance which increases niacin requirement remains unanswered. From early times, the association of pellagra with diets high in maize led to the theory that corn contained a toxic substance which was responsible for the disease. More recently, Woolley (21) administered a concentrate of corn to mice and produced a syndrome which could be prevented or cured by administration of niacin. If a "pellagragenic" factor is present in corn, it might increase niacin requirement by interfering with the utilization of niacin or by inhibiting the conversion of tryptophan to niacin. Studies are in progress in persons maintained on "wheat" diets containing the same levels of niacin and tryptophan as were present in the "corn" diet used in the present study. Findings may assist in solving this problem.

Frazier and Friedemann (2) concluded, from their study of records of pellagragenic and nonpellagragenic diets, that "the minimum daily intake of nicotinic acid in a marginal diet containing corn products is about $7.5 \mathrm{mg}$. per day" and that the niacin requirement may be decreased by improving the quality of the protein in the diet. Data in the present study are in accord with these findings.

Briggs, Singal and Sydenstricker (22) failed to observe an increase in the severity of pellagrous lesions in two subjects with niacin deficiency who 
were maintained for nine to 48 weeks on "corn" diets which, according to present calculations, probably contained 3.6 to $4.2 \mathrm{mg}$. of niacin and 200 to $235 \mathrm{mg}$. of tryptophan. The diet used by these workers was not supplemented with any vitamins and contained less corn and less protein than did the "corn" diet employed in the present study.

Endemic pellagra usually occurs in persons eating diets deficient in many nutrients and some of the lesions encountered have been attributed to deficiency of factors other than niacin. In the present study of niacin requirement, diets were supplemented with other $B$ vitamins and the lesions which developed can be attributed primarily to niacin deficiency. Cheilosis, angular stomatitis and dermatitis of the nasolabial folds, which have been produced in experimental riboflavin deficiency $(23,24)$ and by the administration of desoxypyridoxine (25), were also observed in the present investigation. The occurrence of these lesions in pellagra has previously been attributed to concomitant riboflavin deficiency. Subjects in this study were receiving supplements of $1.5 \mathrm{mg}$. of riboflavin and $5 \mathrm{mg}$. of pyridoxine daily. The requirements for riboflavin or other $B$ vitamins may be increased when the diet is deficient in niacin. This possibility will be explored in future experiments.

The signs of niacin deficiency which developed during the basal corn regimen differed in the three subjects. Mucous membrane lesions predominated in the subject who was affected relatively early, skin lesions in the two subjects in whom deficiency developed later. The severity of glossitis in the three subjects was related to the rate at which deficiency developed. These data corroborate the clinical impression that different lesions may be observed in acute and chronic deficiency states. The occurrence of mucous membrane lesions without dermatitis in one subject substantiates the validity of a diagnosis of niacin deficiency in the absence of skin lesions, i.e., "pellagra sine pellagra," described in the older literature (26).

Many factors may be responsible for the variations in physical signs of nutrient deficiency observed in subjects receiving apparently similar diets under comparable environmental conditions $(27,28)$. Individual nutrient requirements may vary as a result of inherent metabolic pattern, body size, total energy needs, caloric intake, and the body stores of a particular nutrient as well as of all other essential nutrients. The relative quantities of other essential substances in the diet, as well as in the tissues, may play a role in the development of physical signs, in that a deficiency of one nutrient may affect the requirement or utilization of others.

The type and location of lesions may be explained, in part, by tissue susceptibility with local trauma as a precipitating influence (29). The similarity of some of the physical signs appearing in subjects receiving diets deficient in either niacin or riboflavin tends to show a common basis for these signs. It is possible that trauma or the susceptibility of particular tissues in different individuals determines which symptoms appear when any one of several essential nutrients is supplied in insufficient amounts.

Gradual depletion of body stores of a nutrient may lead to a different clinical picture than acute depletion as illustrated by the difference in findings between acute and chronic pellagra. Theoretically, time may permit some type of metabolic adjustment to diminishing nutrient supply. If a nutrient participates in several metabolic processes, requirement may vary for each function with certain pathways having priority. Seasonal changes in metabolism have been suggested as a possible explanation of the seasonal occurrence of pellagra (30). The role of each of the above factors and many others is largely speculative and much more information must be forthcoming before definitive statements can be made.

\section{SUMMARY}

"Corn" and "wheat" diets low in niacin and tryptophan and supplemented with other B vitamins were designed to study niacin requirement in man. Seven subjects who were maintained on these diets for 40 to 135 days were examined frequently for signs of nutritional deficiency, and the urinary excretion of niacin and tryptophan metabolites was determined. The three subjects who received the "corn" diet, which contained about 
$4.7 \mathrm{mg}$. of niacin and $190 \mathrm{mg}$. of tryptophan, for more than 50 days developed clinical signs of pellagra. No clinical evidence of niacin deficiency was observed in two subjects who received the "corn" diet for 42 days, in one subject who received the same diet supplemented with $2 \mathrm{mg}$. of niacinamide daily for 122 days, nor in the subject who received the "wheat" diet containing about $5.7 \mathrm{mg}$. of niacin and $230 \mathrm{mg}$. of tryptophan for 95 days. All subjects remained in nitrogen balance.

In the subjects who developed pellagra, the excretion of $\mathrm{N}^{1}$-methylnicotinamide $\left(\mathrm{N}^{1}-\mathrm{Me}\right)$ decreased to 0.5 to $0.6 \mathrm{mg}$. per day by the 50 th to 60 th day (at which time the first signs of niacin deficiency appeared) and remained at that level. In the subject who received the "corn" diet supplemented with $2 \mathrm{mg}$. of niacinamide daily, excretion of $\mathrm{N}^{1}-\mathrm{Me}$ fell to $0.9 \mathrm{mg}$. per day in 60 days and showed no further decrease. In the subject who received the "wheat" diet, $\mathrm{N}^{1}-\mathrm{Me}$ excretion was $1.1 \mathrm{mg}$. at the end of the experiment on the 95th day. In all subjects, excretion of the 6-pyridone of $\mathrm{N}^{1}$-Me (pyridone) fell to non-detectable levels after the first two weeks. Excretion of niacin, quinolinic acid, and tryptophan remained essentially constant throughout the experimental period in each subject.

In the subjects who developed pellagra, the low excretion of niacin metabolites following administration of a $50 \mathrm{mg}$. test dose of niacinamide at the end of the basal period, and the slow increase in excretion of niacin metabolites following therapy with niacinamide or tryptophan, indicated depletion of body stores of niacin.

Although the "corn" diet was supplemented with riboflavin, the clinical signs of niacin deficiency which developed in subjects in this study included some pellagrous lesions which have previously been attributed to concomitant riboflavin deficiency. All of the lesions which developed in these subjects healed rapidly when the "corn" diet was supplemented with niacinamide or tryptophan.

The findings obtained in this study suggest that with a "corn" diet which provides about $190 \mathrm{mg}$. of tryptophan, the minimal niacin requirement of man is approximately $7 \mathrm{mg}$. per day.
APPENDIX A

"Wheat" diet low in niacin and tryptophan

\begin{tabular}{|c|c|c|c|}
\hline Breakfast & gm. & Supper & gm. \\
\hline Apple juice & 100 & Green beans* & 125 \\
\hline Farina & 20 (dry weight) & White bread & 30 \\
\hline White bread & 40 & Oleomargarine & 17 \\
\hline \multirow[t]{4}{*}{ Oleomargarine } & 20 & Grapejuice & 100 \\
\hline & & Sugar & 10 \\
\hline & & Fruit cocktail or & 150 \\
\hline & & Apple sauce* & 150 \\
\hline \multicolumn{2}{|l|}{ Dinner } & \multicolumn{2}{|l|}{ Between Meals } \\
\hline \multirow{11}{*}{$\begin{array}{l}\text { Mor beef } \\
\text { Rice } \\
\text { Beets or } \\
\text { Carrots* } \\
\text { White bread } \\
\text { Oleomargarine } \\
\text { Apple juice }\end{array}$} & 20 & \multicolumn{2}{|l|}{3 p.m. } \\
\hline & 42 (dry weight) & Cookies & 40 \\
\hline & 100 & Lemon juice & 30 \\
\hline & 125 & Sugar & 20 \\
\hline & 30 & & \\
\hline & 20 & \multicolumn{2}{|l|}{8 p.m. } \\
\hline & 200 & Prune juice & 100 \\
\hline & & Gelatin & 20 \\
\hline & & Sugar & 20 \\
\hline & & Pears or & 100 \\
\hline & & Pineapple* & 100 \\
\hline
\end{tabular}

* Canned, drained weight, given alternately.

White flour (Gold Medal) and farina were unenriched.

Analysis of diet: nitrogen $7.0 \mathrm{gm}$., niacin $5.7 \mathrm{mg}$., tryptophan $230 \mathrm{mg}$.

Energy value: approximately 1,900 calories.

APPENDIX B

Recipes used in "corn" and "wheat" diets

White Bread-1 loaf

$\begin{array}{lr}\text { Unenriched flour } & 350 \mathrm{gm} . \\ \text { Salt } & 7 \mathrm{gm} . \\ \text { Sugar } & 10.5 \mathrm{gm} . \\ \text { Yeast } & 10.5 \mathrm{gm} . \\ \text { Fat (hydrogenated vegetable) } & 6.5 \mathrm{gm} . \\ \text { Water } & 200 \mathrm{gm} .\end{array}$

Cooked weight, $520-550 \mathrm{gm}$.

Baked 15 min. at $425^{\circ} \mathrm{F}$. then $35 \mathrm{~min}$. at $350^{\circ} \mathrm{F}$.

\begin{tabular}{lr} 
Unenriched flour & \\
Sugar & $100 \mathrm{gm}$. \\
Oleomargarine & $68 \mathrm{gm}$. \\
Baking powder & $30 \mathrm{gm}$. \\
Salt & $8 \mathrm{gm}$. \\
Water & $2 \mathrm{gm}$. \\
\hline
\end{tabular}

Cooked weight, 210-220 gm.

Baked 15 minutes at $500^{\circ} \mathrm{F}$.

Biscuits

$\begin{array}{lr}\text { Unenriched flour } & 100 \mathrm{gm} . \\ \text { Baking powder } & 8 \mathrm{gm} . \\ \text { Salt } & 2 \mathrm{gm} . \\ \text { Fat (hydrogenated vegetable) } & 12 \mathrm{gm} . \\ \text { Water } & 80 \mathrm{gm} .\end{array}$

Cooked weight, 170-180 gm.

Baked 15 min. at $500^{\circ} \mathrm{F}$. 


\section{Corn Bread}

Cornmeal, degerminated

Unenriched flour

Fat (hydrogenated vegetable)

Sugar

Salt

Baking powder

Water

$100 \mathrm{gm}$.

$33 \mathrm{gm}$.

$15 \mathrm{gm}$.

$3.5 \mathrm{gm}$.

$1.5 \mathrm{gm}$.

$8 \mathrm{gm}$.

$130 \mathrm{gm}$.

Cooked weight, 250-260 gm.

Baked $30 \mathrm{~min}$. at $500^{\circ} \mathrm{F}$.

\section{REFERENCES}

1. Dann, W. J., The human requirement for nicotinic acid. Federation Proc., 1944, 3, 159.

2. Frazier, E. I., and Friedemann, T. E., Pellagra, a study in human nutrition. The multiple-factor principle of the determination of minimum vitamin requirements. Quart. Bull., Northwestern Univ. M. School, 1946, $20,24$.

3. Sarett, H. P., and Goldsmith, G. A., The effect of tryptophane on the excretion of nicotinic acid derivatives in humans. J. Biol. Chem., 1947, 167, 293.

4. Perlzweig, W. A., Rosen, F., Levitas, N., and Robinson, J., The excretion of nicotinic acid derivatives after ingestion of tryptophane by man. J. Biol. Chem., 1947, 167, 511.

5. Sarett, H. P., and Goldsmith, G. A., Tryptophan and nicotinic acid studies in man. J. Biol. Chem., 1949, 177, 461.

6. Rose, W. C., Amino acid requirements of man. Federation Proc., 1949, 8, 546.

7. Najjar, V. A., and Holt, L. E., Jr., The excretion of specific fluorescent substances in the urine in pellagra. Science, 1941, 93, 20.

8. Huff, J. W., and Perlzweig, W. A., $\mathrm{N}^{1}$-methylnicotinamide, a metabolite of nicotinic acid in the urine. J. Biol. Chem., 1943, 150, 395.

9. Knox, W. E., and Grossman, W. I., A new metabolite of nicotinamide. J. Biol. Chem., 1946, 166, 391.

10. Huff, J. W., and Perlzweig, W. A., The fluorescent condensation product of $\mathrm{N}^{1}$-methylnicotinamide and acetone. II. A sensitive method for the determination of $\mathrm{N}^{1}$-methylnicotinamide in urine. J. Biol. Chem., 1949, 167, 157.

11. Rosen, F., Perlzweig, W. A., and Leder, I. G., A fluorometric method for the determination of the 6-pyridone of $\mathrm{N}^{1}$-methylnicotinamide in urine. $\mathrm{J}$. Biol. Chem., 1949, 179, 157.

12. Krehl, W. A., Strong, F. M., and Elvehjem, C. A., Determination of nicotinic acid. Modifications in the microbiological method. Indust. \& Engin. Chem. (Analyt. Ed.), 1943, 15, 471.
13. Kuiken, K. A., Lyman, C. M., and Hale, F., Factors which influence the stability of tryptophan during the hydrolysis of proteins in alkaline solutions. J. Biol. Chem., 1947, 171, 551.

14. Sarett, H. P., Quinolinic acid excretion and metabolism in man. J. Biol. Chem., 1951, 193, 627.

15. Saunders, E. B., The gynecological, obstetrical and surgical aspects of pellagra; a preliminary study. Am. J. Insan., 1910-11, 67, 541.

16. Bean, W. B., Spies, T. D., and Blankenhorn, M. A., Secondary pellagra. Medicine, 1944, 23, 1.

17. Vilter, R. W., Mueller, J. F., and Bean, W. B., The therapeutic effect of tryptophane in human pellagra. J. Lab. \& Clin. Med., 1949, 34, 409.

18. Sarett, H. P., and Goldsmith, G. A., Metabolism of $\mathrm{L}$ - and DL-tryptophan in normal man and in pellagrins. J. Biol. Chem., 1950, 182, 679.

19. Bean, W. B., Franklin, M., and Daum, K., A note on tryptophane and pellagrous glossitis. J. Lab. \& Clin. Med., 1951, 38, 167.

20. Krehl, W. A., Sarma, P. S., Teply, L. J., and Elvehjem, C. A., Factors affecting the dietary niacin and tryptophane requirement of the growing rat. J. Nutrition, 1946, 31, 85.

21. Woolley, D. W., The occurrence of a "pellagragenic" agent in corn. J. Biol. Chem., 1946, 163, 773.

22. Briggs, A. P., Singal, S. A., and Sydenstricker, V. $P .$, A study of nicotinic acid restriction in man. J. Nutrition, 1945, 29, 331.

23. Sebrell, W. H., and Butler, R. E., Riboflavin deficiency in man; preliminary note. Public Health Rep., 1938, 53, 2282.

24. Horwitt, M. K., Hills, O. W., Harvey, C. C., Liebert, E., and Steinberg, D. L., Effects of dietary depletion of riboflavin. J. Nutrition, 1949, 39, 357.

25. Mueller, J. F., and Vilter, R. W., Pyridoxine deficiency in human beings induced with desoxypyridoxine. J. Clin. Invest., 1950, 29, 193.

26. Harris, H. F., Pellagra. The Macmillan Co., New York, 1919, p. 234.

27. Kruse, H. D., A concept of the etiological complex of deficiency states with especial consideration of conditions. Milbank Mem. Fund. Quart., 1949, 27, 5.

28. Darby, W. J., Evaluation of the symptoms and signs of deficiency diseases. Federation Proc., 1950, 9, 592.

29. Hills, O. W., Liebert, E., Steinberg, D. L., and Horwitt, M. K., Clinical aspects of dietary depletion of riboflavin. Arch. Int. Med., 1951, 87, 682.

30. Sargent, F., and Sargent, V. W., Season, nutrition and pellagra. New England J. Med., 1950, 242, 447, 507. 